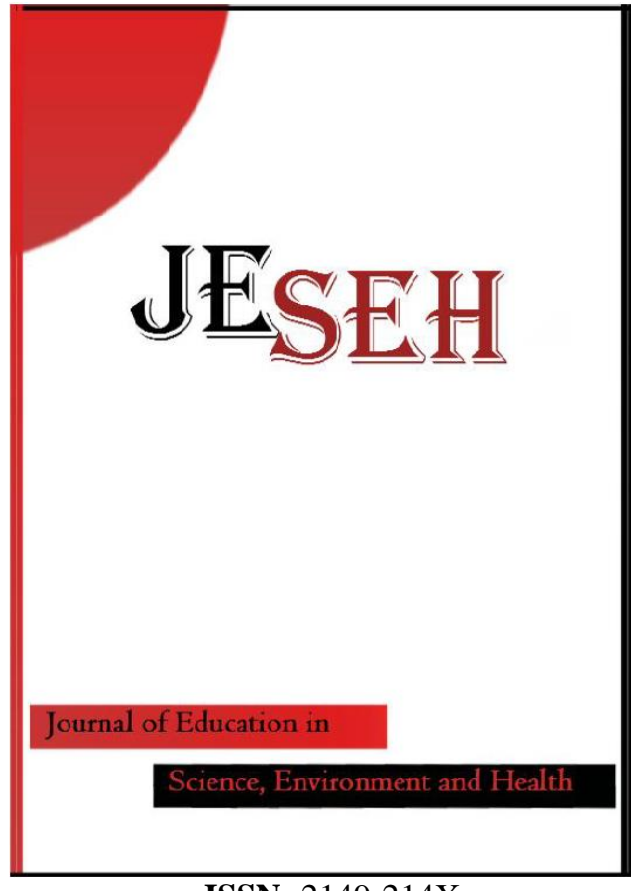

ISSN: $2149-214 \mathrm{X}$

\section{Journal of Education in Science,} Environment and Health

$\underline{\text { www.jeseh.net }}$

Correlation between Understanding about Nature of Science and Orientation to Teaching Science: An Exploratory Study with Thai First-Year Preservice Biology Teachers

Luecha Ladachart

University of Phayao

To cite this article:

Ladachart, L. (2019). Correlation between understanding about nature of science and orientation to teaching science: An exploratory study with Thai first-year preservice biology teachers. Journal of Education in Science, Environment and Health (JESEH), 5(1), 134-145. DOI:10.21891/jeseh.512428

This article may be used for research, teaching, and private study purposes.

Any substantial or systematic reproduction, redistribution, reselling, loan, sub-licensing, systematic supply, or distribution in any form to anyone is expressly forbidden.

Authors alone are responsible for the contents of their articles. The journal owns the copyright of the articles.

The publisher shall not be liable for any loss, actions, claims, proceedings, demand, or costs or damages whatsoever or howsoever caused arising directly or indirectly in connection with or arising out of the use of the research material. 


\title{
Correlation between Understanding about Nature of Science and Orientation to Teaching Science: An Exploratory Study with Thai First- Year Preservice Biology Teachers
}

\author{
Luecha Ladachart
}

\begin{tabular}{|c|c|}
\hline Article Info & Abstract \\
\hline Article History & $\begin{array}{l}\text { Research in teacher education has given increasing attention to pedagogical } \\
\text { content knowledge (PCK) as a theoretical construct that describes necessary }\end{array}$ \\
\hline $\begin{array}{l}\text { Received: } \\
21 \text { October } 2018\end{array}$ & $\begin{array}{l}\text { knowledge for teachers to teach specific content. This research study aims to } \\
\text { examine whether an understanding about the nature of science (NOS) correlates }\end{array}$ \\
\hline $\begin{array}{l}\text { Accepted: } \\
\text { 31 December } 2018\end{array}$ & $\begin{array}{l}\text { with orientation to teaching science (OTS), which is an overarching component } \\
\text { of PCK for teaching science. Nineteen first-year preservice biology teachers } \\
\text { completed adapted versions of an open-ended questionnaire called V-NOS and a }\end{array}$ \\
\hline Keywords & $\begin{array}{l}\text { multiple-choice OTS test called POSST whose data were transformed and then } \\
\text { analyzed using Pearson's correlation. The results reveal a slightly negative }\end{array}$ \\
\hline $\begin{array}{l}\text { Nature of science } \\
\text { Science teaching } \\
\text { orientation }\end{array}$ & $\begin{array}{l}\text { correlation between these two variables, which is not statistically significant }(\mathrm{r}= \\
-.227, \mathrm{p}=.351) \text {. This result suggests that understanding of the NOS may not be } \\
\text { a dimension of OTSs, so facilitating understanding of the NOS may not }\end{array}$ \\
\hline $\begin{array}{l}\text { Pedagogical content } \\
\text { knowledge }\end{array}$ & necessarily lead to inquiry-based OTSs. \\
\hline
\end{tabular}

\section{Introduction}

Since Shulman (1986) introduced a theoretical construct called pedagogical content knowledge (PCK) to describe necessary knowledge for teaching specific content, this construct has been elaborated further to guide science teacher education and research (Abell, 2008). Magnusson, Krajcik, \& Borko (1999), for example, identify five components of PCK for teaching science, which include (a) orientations toward teaching science (OTSs), (b) knowledge and beliefs of science curricula, (c) knowledge and beliefs of students' understanding of science, (d) knowledge and beliefs of assessment of scientific literacy and (e) knowledge and beliefs of instructional strategies. The first component is defined as "knowledge and beliefs about the purposes and goals for teaching science" (p. 97), which overarches and interacts with the other four components when science teachers develop and use PCK. OTSs can serve as a filter for science teachers learning to teach specific content of science (Avraamidou 2013) and as a lens to understand science teachers' classroom practices (Boesdorfer \& Lorsbach, 2014).

Despite its influential roles, OTSs are often taken for granted in the PCK research movement. A critical review by Friedrichsen, van Driel, \& Abell (2011) revealed that OTSs are used in different or unclear ways with unclear or absent relationships with the other components. As a result, their nature becomes an issue in many ways. First, as Veal \& Makinster (1999) suggest three levels of PCK (i.e., general PCK, domain-specific PCK, and topic-specific PCK), it is not clear whether OTSs are general or domain/topic-specific. Second, as Friedrichsen \& Dana (2005) found, beliefs about students can serve as a source of OTSs, so it is not clear whether OTSs would vary according to students' grade levels with different educational purposes. Third, there is a lack of agreement on whether views of science should be a dimension of OTSs (Friedrichsen et al., 2011; Kind, 2016). One agreement seems to be that contexts where science teachers work can influence their OTSs (Friedrichsen \& Dana, 2005; Ramnarain \& Schuster, 2014; Ramnarain, Nampota, \& Schuster, 2016) or at least influence the translation of their OTSs into classroom practices (Nargund-Joshi, Park Rogers, \& Akerson, 2011). Hence, as Abell (2008) argued, OTSs deserve more attention in the research if this construct is to be useful in guiding science teacher education.

Whereas previous studies have focused on exploring OTSs held by experienced science teachers (e.g., Boesdorfer \& Lorsbach, 2014; Faikhamta, 2013; Friedrichsen \& Dana, 2005; Nargund-Joshi et al., 2011; Park \& Chen, 2012; Ramnarain \& Schuster, 2014; Ramnarain et al., 2016) or preservice science teachers with a few years in university (e.g., Avraamidou, 2013; Brown, Friedrichsen, \& Abell, 2013; Demirdogen, 2016; Eick \& Reed, 2002; Kind, 2016), a few studies, if any, have investigated OTSs held by first-year preservice science 
teachers who just entered science teacher education. Given that preservice science teachers have developed conceptions of teaching and learning, a dimension of OTSs according to Friedrichsen et al. (2011), since they were students (Lortie, 1975), a lack of research in this area with freshmen preservice science teachers becomes a shortcoming because their initial OTSs can play significant roles when engaging in science teacher education activities and coursework. Better understanding of their initial OTSs can help inform how science teacher education can be designed to facilitate their development of OTSs and PCK.

\section{Theoretical Framework}

More than 30 years ago, Shulman (1986) had introduced PCK as a theoretical construct to describe a unique kind of knowledge for teaching specific content. This kind of knowledge "goes beyond knowledge of subject matter per se" (p. 9) as teachers must also know how to pedagogically make such content or subject matter accessible and understandable to students with different abilities and backgrounds (Shulman, 1987). It is this special kind of knowledge that distinguishes teachers from content specialists. After its introduction, PCK has gained much attention because it aligns well with the current change in the educational paradigm which has undergone a shift from behaviorism with the emphasis on teachers' behaviors to constructivism with the emphasis on teachers' knowledge, beliefs and learning to teach (Richardson, 1991). Consequently, research on science teacher education has become devoted to developing science teachers' PCK in the various topics of science (van Driel, Verloop, \& de Vos, 1998).

In this movement, Magnusson et al. (1999) has proposed a model of PCK for teaching science, which includes five components, as previously mentioned. OTSs are the overarching component that plays influential roles as they interact with the other four components. They also provide a list of nine different OTSs as found in the literature (i.e., process, academic rigor, didactic, conceptual change, activity-driven, discovery, project-based science, inquiry and guided inquiry). However, Friedrichsen et al. (2011) argued that some of these OTSs may overlap each other and that they may not be empirically supported by research with science teachers. Instead, they tend to represent OTSs as reflected in recommended instructional approaches of science curriculum development projects or contemporary reform-based projects. Therefore, to ensure empirically supported OTSs, Kind (2016) explored OTSs held by preservice science teachers by which she confirmed five OTSs (i.e., didactic, academic rigor, activity-driven, conceptual change and inquiry). In Thailand, which is the context of the present study, Faikhamta (2013) found five OTSs held by in-service science teachers (i.e., project-based science, process, guided inquiry, activity-driven and discovery).

Nonetheless, Friedrichsen et al. (2011) argued that a science teacher's OTSs can be complex and messy to be assigned as one specific type, and that he or she may simultaneously have more than one OTSs. In such cases, some of them are central, while the others are peripheral (Friedrichsen \& Dana, 2005). Thus, researchers are cautioned not to identify one OTS for a science teacher too early. However, as an analysis of a science teacher's OTSs can be a time- and effort-consuming process (Friedrichsen \& Dana, 2003), OTSs can be formatively assessed and then be used to inform a science teacher education program. Cobern et al. (2014) have developed a case-based assessment called a Pedagogy of Science Teaching Test (POSTT) to identify four common OTSs associated with the current science education reform. Those four OTSs can be viewed as a spectrum of two variants of direct instruction (i.e., didactic direct and active direct) and two variants of inquiry (i.e., guided inquiry and open inquiry). The two variants of direct instruction share a fundamental epistemic mode of readymade science while the two variants of inquiry reflect that of science-in-the-making. On the side of direct instruction, didactic direct reflects a passive mode in nature, while active direct reflects a more hands-on or activity-based one. On the side of inquiry, the difference between the two is the extent of science teachers' scaffolding and students' independence in doing scientific investigation.

While the nature and types of OTSs can be issues, research consistently establishes that OTSs not only influence how science teachers decide to teach science (Boesdorfer \& Lorsbach, 2014) but also how they develop PCK (Brown et al. 2013). For example, Park \& Chen (2012) found that a didactic OTS held by a science teacher can direct his or her knowledge of instructional strategies, and that such connection can inhibit connections with other PCK components. In opposition, Eick \& Reed (2002) found that preservice science teachers with a strong inquiry OTS not only benefit from supporting experiences in science teacher education with an emphasis on inquiry-based instruction, but also more easily put their facilitating roles into action when they support students' scientific inquiries. Given the significance of OTSs, science teacher education programs should facilitate preservice science teachers having inquiry-based OTSs as early as possible so that they can further facilitate the development of PCK. Certain experiences can potentially shape preservice science teachers' OTSs toward 
inquiry such as inquiry-based investigations, contemporary theoretical discussions, outdoor field study, friendly classroom environments and characteristics of the instructors (Avraamidou, 2013).

While inquiry-based OTSs can be facilitated during science teacher education programs, research also suggests that the contexts in which science teachers work can influence their OTSs (Friedrichsen \& Dana, 2005). Using Cobern et al.'s (2014) POSTT, Ramnarain \& Schuster (2014) compared OTSs held by two groups of science teachers working in different school contexts in South Africa. They found that science teachers at disadvantaged township schools tend to have a strong 'active direct' OTS while those at suburban schools tend to exhibit a 'guided inquiry' OTS. Similar results were found in their comparative study in South Africa and Malawi, showing that science teachers at more privileged schools show stronger guided- and open-inquiry OTSs than those at less privileged schools (Ramnarain et al., 2016). Such difference in OTSs may result from contextual factors in schools such as class size, availability of resources, time constraints, student ability, school culture and parents' expectations (Ramnarain \& Schuster, 2014). Nargund-Joshi et al. (2011) also found that science teachers with a reform-based OTS can encounter difficulties in putting it in classroom practice due to contextual constraints such as large classes, limited time and a strong emphasis on external examination. It is likely that such experienced difficulties may in turn undermine their reform-based OTS towards a more didactic one.

As previously mentioned, there are some issues about the nature of the OTSs in the literature. In the present study, the focus is on one issue-that is, whether OTSs correlate with a view or understanding of the NOS, which can be explained by some key aspects such as scientific knowledge is empirically based, partially subjective and subject to change (Lederman, 1992). This issue came into being as Friedrichsen et al. (2011) proposed that the view of science may be a dimension of OTSs. This proposal aligns with some research findings showing interrelation between science teachers' beliefs of teaching, learning and science (e.g., Tsai, 2002). A relationship between reform-based OTSs and informed understanding of the NOS can be expected given the fact that they both reflect an epistemology of science-in-the-making. Moreover, as research suggests that inquiry-based instruction can both facilitate inquiry-based OTSs (Avraamidou, 2013; Britner \& Finson, 2005) and be a context for explicitly addressing NOS aspects (Abd-El-Khalick \& Lederman, 2000), it is reasonable to expect that OTSs and the NOS can be facilitated simultaneously with appropriate scaffoldings. However, Kind (2016) found that this may not be the case. Rather than being a dimension of OTSs, NOS should be "considered to be subject-specific content" (Faikhamta 2013, p. 850), not even taking part in Magnusson et al.'s (1999) model of PCK. It is this issue that the present study was designed to address.

\section{Research questions}

This research study aims to make the issue regarding the nature of OTSs clearer. It aims to address two research questions as follows:

1. What are first-year preservice biology teachers' OTSs?

2. Do first-year preservice biology teachers' OTSs correlate to their understanding about nature of science (NOS)?

\section{Research methods}

\section{Context}

This study took place in a university in the northern region of Thailand whose science education program is quite unique. It is locally called a 5-year parallel program in the sense that preservice science teachers study simultaneously in two curricula collaboratively developed by two faculties (i.e., School of Science and School of Education). Once they complete the requirements of these curricula, they receive two bachelor's degrees, both in Science and in Education. In this, preservice science teachers must study several science courses as well as educational courses as required by the Teachers' Council of Thailand before they receive a professional license and are qualified to teach in government or private schools.

\section{Participants}

Participants in this study were 19 first-year preservice biology teachers who are engaged in the 5-year parallel program. The participants included 5 males and 14 females with GPA ranging between 2.02 and $3.39(\mathrm{M}=2.61$, 
$\mathrm{SD}=0.40)$. All the participants were purposively selected for convenient reasons as they had enrolled in a course called Self-Actualization for Professional Teachers, which aims to introduce them to their future roles and duties as science teachers as well as the laws and rules for teachers. Before this course, they had finished only one educational course, which was Educational Philosophy, since it was their second semester in the program during the study. They had passed neither any course on the NOS nor any course on the inquiry-based method.

\section{Instruments}

Orientation to teaching science

An instrument called POSTT (Cobern et al., 2014) was adapted and then used to gather data about the participants' OTSs. It was a case-based assessment in that the participants were presented with instructional scenarios in which they were asked to make decisions for action. For example, a scenario would be that a science teacher was teaching frog dissection. Then, the question that would be asked was, if the participants were in that teacher's place, what kind of action they would take to facilitate students' learning. In this assignment, the participants had four choices from which to select. Each choice corresponded to one in the spectrum of OTSs (i.e., didactic direct, active direct, guided inquiry and open inquiry), so it was possible to transform the participants' OTSs into quantitative data. Figure 1 illustrates one item of the POSTT.

Mr. Goodchild is doing a frog dissection with his $10^{\text {th }}$ graders to help teach about anatomy.

Thinking about how you would teach a lesson, of the following, which is most similar to what you believe is the best way to incorporate a dissection into a lesson?

A. It should be used as a stand-alone step-by-step activity for students to explore the frog's anatomy and raise discussion questions on their own. [Open inquiry]

B. It should be used as a follow-up step-by-step student activity after Mr. Goodchild explains exactly what students will need to notice about the frog anatomy. [Active direct]

C. It should be used as a step-by-step student activity while answering probing questions, followed up by teacher-led discussion and clarifications. [Guided inquiry]

D. It should be used as a step-by-step demonstration by Mr. Goodchild while he explicitly points out what students need to know about frog anatomy. [Didactic direct]

Figure 1. An example of the POSTT item (Cobern et al., 2014).

There were 16 items of the POSTT, and these items cover a number of science topics. According to Thailand's National Core Science Curriculum Standards (Bureau of Academic Affairs and Educational Standards 2010), students in basic education must learn science in eight strands, which include (1) living things and processes of life, (2) life and the environment, (3) substances and properties of substances, (4) force and motion, (5) energy, (6) change processes of the earth, (7) astronomy and space, and (8) nature of science and technology. Except for the last one, these strands can be categorized into three groups (i.e., biological sciences for the first two strands, physical sciences for the following three strands, and astronomical and earth sciences for the last two strands). There were five items for biological science, six for physical sciences, and five for astronomical and earth sciences. While the original POSTT does indicate students' educational levels in its scenarios, which may be different from what are specified in Thailand's National Core Science Curriculum Standards, the students' educational levels in the scenarios were adapted in order to be consistent with the context of the study. Table 1 shows the structure of the POSTT as used in the study.

The POSTT was translated from English into Thai and reviewed back and forth to ensure that its essential meanings were intact. Also, the original and the translated POSTT were sent to two science education researchers to check the translations, and they were improved according to the feedback and comments of the researchers. Once the translation was up to the satisfactory level, the translated POSTT was tried out with eight preservice science teachers who had studied in a nearby university. In doing so, a blank space was provided for those preservice science teachers to write their reasons so that it could be checked if their answers were consistent or contradicted with the reasons they provided, signaling their interpretation of each item. Feedback from this try-out led to the improvement of the POSTT to be used in the study. 
Table 1. Structure of POSTT instruments.

\begin{tabular}{|c|c|c|c|c|c|c|}
\hline \multirow[b]{2}{*}{ Item } & \multicolumn{3}{|c|}{ Content } & \multicolumn{3}{|c|}{ Students' educational level } \\
\hline & Biological & Physical & $\begin{array}{l}\text { Astronomical } \\
\text { and Earth }\end{array}$ & $\begin{array}{c}\text { Lower } \\
\text { Primary }\end{array}$ & $\begin{array}{l}\text { Higher } \\
\text { Primary }\end{array}$ & Secondary \\
\hline 1 & $\checkmark$ & & & & & $\checkmark$ \\
\hline 2 & $\checkmark$ & & & & & $\checkmark$ \\
\hline 3 & & & $\checkmark$ & & $\checkmark$ & \\
\hline 4 & & $\checkmark$ & & & $\checkmark$ & \\
\hline 5 & & $\checkmark$ & & & $\checkmark$ & \\
\hline 6 & & & $\checkmark$ & & $\checkmark$ & \\
\hline 7 & $\checkmark$ & & & $\checkmark$ & & \\
\hline 8 & $\checkmark$ & & & & $\checkmark$ & \\
\hline 9 & $\checkmark$ & & & & & $\checkmark$ \\
\hline 10 & & & $\checkmark$ & & & $\checkmark$ \\
\hline 11 & & & $\checkmark$ & $\checkmark$ & & \\
\hline 12 & & $\checkmark$ & & $\checkmark$ & & \\
\hline 13 & & $\checkmark$ & & & & $\checkmark$ \\
\hline 14 & & $\checkmark$ & & & $\checkmark$ & \\
\hline 15 & & $\checkmark$ & & $\checkmark$ & & \\
\hline 16 & & & $\checkmark$ & & & $\checkmark$ \\
\hline Sum & 5 & 6 & 5 & 4 & 6 & 6 \\
\hline
\end{tabular}

\section{Understanding of NOS}

Views of Nature of Science Questionnaire (VNOS, Lederman et al., 2002) was adapted to elicit the participants' understanding of the NOS. It is an open-ended questionnaire, which consists of seven items, asking the participants to write their responses regarding the six aspects of the NOS: (1) that scientific knowledge has basis in empirical evidence (empirical NOS), (2) that scientific knowledge involves making inference based on evidences (inferential NOS), (3) that scientific knowledge is influenced and driven by scientists' personal subjectivity (subjective NOS), (4) that scientific knowledge is the product of human creativity and imagination (creative and imaginative NOS), (5) that scientific knowledge is subject to change (tentative NOS) and (6) that science is a human enterprise embedded in the practices of the society and culture (sociocultural NOS). Most of the items are context-free (e.g., 'What is science?', 'What makes science different from other disciplines?', 'Does scientific knowledge ever change?' and 'Do scientists use their creativity and imagination during their investigation?'). Some of the items, however, are contextualized to help the participants express their understanding of some aspects (e.g., 'How do scientists know about the characteristics of dinosaurs which became extinct million years ago?' and 'How are scientists sure about weather conditions as predicted by computer simulation?'). Similar to the POSTT, the VNOS was translated from English into Thai and reviewed back and forth to ensure that its essential meanings were not missed. Then, the original and the translated VNOS were sent to the same science education researchers to check the translations, and they were improved according to the researchers' feedback and comments until the translation was up to the satisfactory level. The translated VNOS was also tried with secondary students.

\section{Data collection}

Data collection was carried out the first time the participants attended the class. During the data collection, they were asked to complete the modified POSTT; they were encouraged by the fact that its results will expose their preference with regard to some specific ways of teaching science. They were also informed that there were no right or wrong answers for this measurement and that its results will not affect their grade of the course being studied. They were also advised that in cases where the given choices do not totally reflect their instructional preference, they could choose the one best aligned with their preference. They were also encouraged to provide reasons supporting their answers in all items so that it would be possible to examine whether they understood the items and whether there was any inconsistency between the chosen answers and the written reasons. The participants took approximately one and a half hours to complete the modified POSTT. A week later, the participants were asked to complete an adapted VNOS with a similar administration. In the assignment, they were encouraged to write with details and examples that illustrate their understanding of science. They were also informed that their responses were not evaluated as right or wrong, but were considered as showing how they 
viewed science as a discipline that they would be teaching in future. They took about 45 min to complete the questionnaire.

\section{Data analysis}

Data analysis for the modified POSTT was based on a scoring system in which 1 point was given for each answer representing a didactic-direct OTS, 2 points for an active-direct OTS, 3 points for a guided-inquiry OTS and 4 points for an open-inquiry OTS as an increase in the number of points reflects an instructional tendency that is more inclined towards scientific inquiry. As a result, each participant can possibly have a total score in the range of 16-64 points. This scoring system allowed the researchers to determine each participant's mean score (M) and standard deviation (SD). On using the Shapiro-Wilk test (Morgan et al., 2013), it was found that the OTS data were normally distributed at $.05(\mathrm{~W}=.941, \mathrm{p}=.277)$ with an average score at $2.37(\mathrm{SD}=0.34)$, suggesting that the participants tended to have OTSs between 'active direct' (2) and 'guided inquiry' (3). However, as shown in Table 2, four participants had average scores lower than 2.00, reflecting the didactic nature of their OTSs.

Table 2. Participants' OTS scores on modified POSST OTSs.

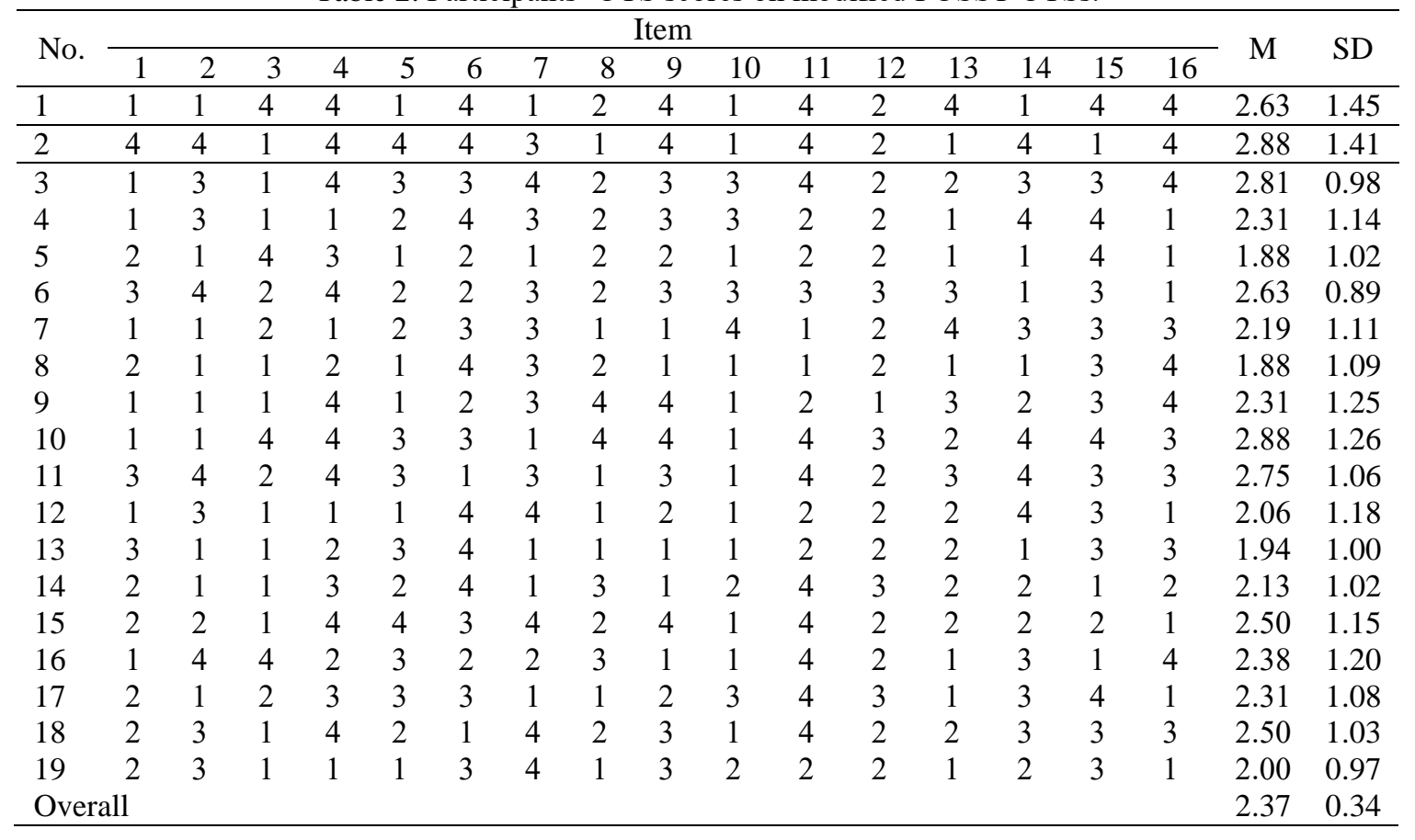

In analyzing data regarding the participants' understanding of NOS in response to the adapted VNOS, instead of categorizing them into three categories as naïve, transitional and informed in an evaluative manner, the focus was placed on the potential of their understanding of NOS. In the process, their written answers were read and reread. Then, each sentence was coded if it reflected specific aspects of the NOS. As illustrated in Table 3, if a sentence referred to evidence, in either specific or general sense (e.g., fossils or observation, respectively), as necessary for making scientific knowledge, it was coded as empirical NOS. Also, if a sentence referred to making inference based on available evidence, it was coded as inferential NOS accordingly. In doing so, it was notable that one sentence could reflect more than one aspect of NOS. For instance, participant no. 2 wrote, "From fossils found, (scientists) compare with animals at present and infer accordingly (for what they ate)". An empirical NOS code was provided for the fossil found as it is required to make scientific knowledge about dinosaurs. For the same sentence, an inferential NOS was provided as it clearly stated that only fossils are not sufficient for scientists to make a conclusion about dinosaurs. Such a sentence reflects not only an understanding of the two NOS aspects but also the relationship between them. However, it was also noticeable that none of the written responses can be coded as sociocultural NOS. Perhaps, this is because sociocultural influence on science is largely ignored in Thailand's science education. Thus, this aspect was excluded in further analysis. Once individually done, the coded data were shared and discrepancies discussed until a satisfactory consensus was reached. 
Table 3. Examples of coding participants' written responses regarding NOS.

\begin{tabular}{|c|c|c|}
\hline Code & Meaning & Illustrative Example \\
\hline Empirical NOS & $\begin{array}{l}\text { Scientific knowledge has basis } \\
\text { in empirical evidence. }\end{array}$ & $\begin{array}{l}\text { "(Science) has experiments to find } \\
\text { facts to refute arguments." (no. 12) }\end{array}$ \\
\hline Inferential NOS & $\begin{array}{l}\text { Scientific knowledge involves } \\
\text { making inference based on } \\
\text { evidence. }\end{array}$ & $\begin{array}{l}\text { "From fossils found, (scientists) } \\
\text { compare with animals at present and } \\
\text { infer accordingly." (no. 2) }\end{array}$ \\
\hline Subjective NOS & $\begin{array}{l}\text { Scientific knowledge is } \\
\text { influenced and driven by } \\
\text { scientists' personal subjectivity. }\end{array}$ & $\begin{array}{l}\text { "Each (scientist) may have a different } \\
\text { point of view." (no. 2) }\end{array}$ \\
\hline Imaginative/Creative NOS & $\begin{array}{l}\text { Scientific knowledge is the } \\
\text { product of human creativity and } \\
\text { imagination. }\end{array}$ & $\begin{array}{l}\text { "If hypotheses are made without } \\
\text { imagination about what we find, we } \\
\text { may not get new ones." (no. 2) }\end{array}$ \\
\hline Tentative NOS & $\begin{array}{l}\text { Scientific knowledge is subject } \\
\text { to change. }\end{array}$ & $\begin{array}{l}\text { "Scientific (knowledge) is not } \\
\text { certain; (it) can change." (no. 12) }\end{array}$ \\
\hline
\end{tabular}

In further analysis, each biology teacher's understanding of five NOS aspects was mapped into a pentagon. Each angle of the pentagon represents one NOS aspect, while the connecting line between two angles represents the relationship between their corresponding NOS aspects. The number at each angle represents the frequency of the participant mentioning each NOS aspect, while the number close to each line represents the frequency of the participant making the connection between the two NOS aspects.

As illustrated in Figure 2, participant no. 12 made sentences referring to the empirical NOS 6 times, out of which only once was his sentence coded as the tentative NOS. He also made the connection between these two NOS aspects 4 times. Using this method, each participant's understanding of NOS was graphically presented. This is also helpful to visualize which aspects he or she was certain about and which ones he or she was less certain about or did not even comprehend correctly. Using frequency numbers representing each NOS aspect and those representing each connection between two NOS aspects, it was found that the data regarding NOS were not normally distributed at $.05(\mathrm{~W}=.878, \mathrm{p}=.001$ ), based on the Shapiro-Wilk test (Morgan et al., 2013). This is because, as summarized in Table 4, most of the participants lacked proper understanding of some NOS aspects. Nonetheless, there was found a tendency that the more the participants referred to the NOS aspects, the more they made a connection between them as the Pearson's correlation coefficient was high $(\mathrm{r}=.940, \mathrm{p}=$ $.000)$.

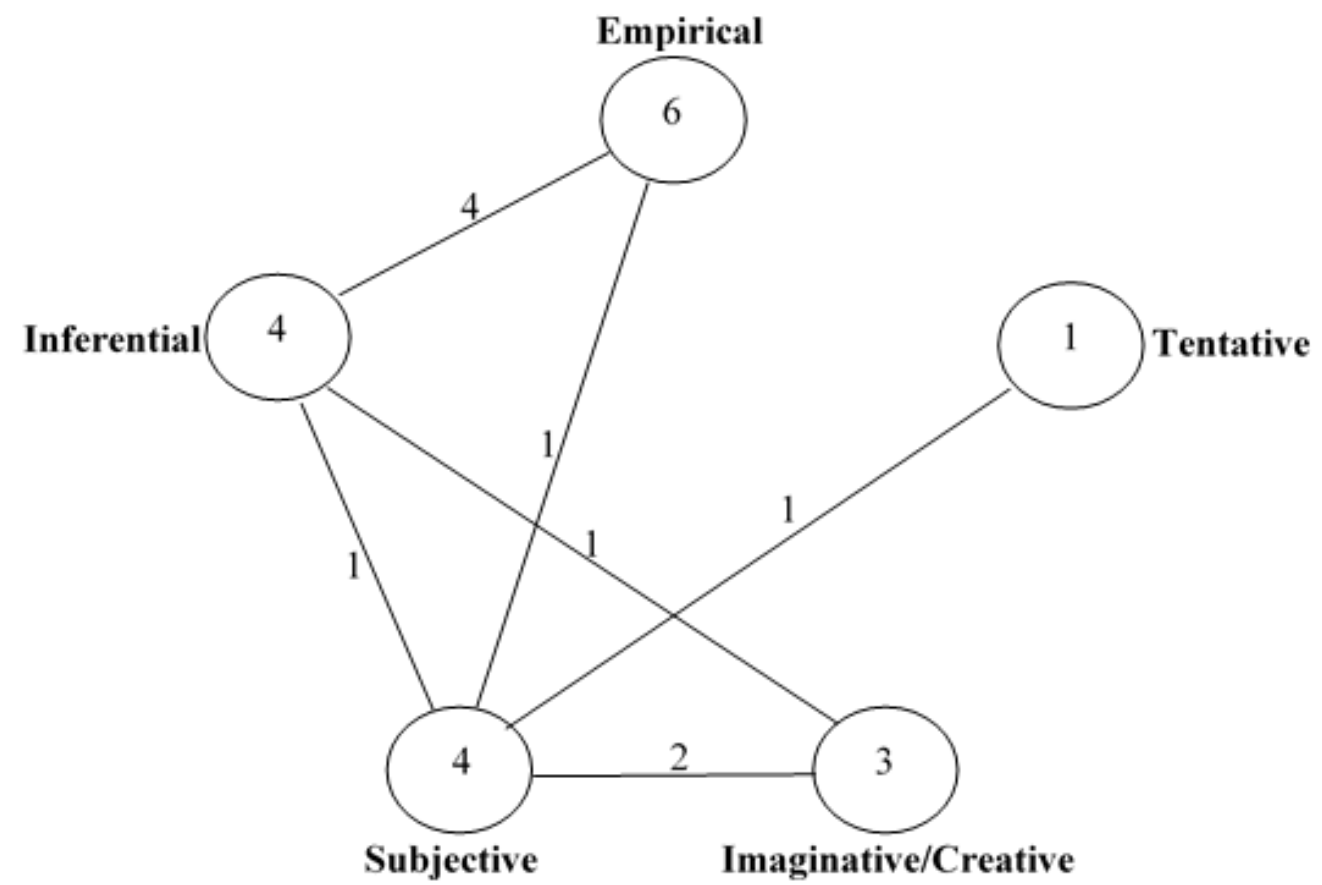

Figure 2. Participant no. 12's understanding of the NOS, as represented by a pentagon 
Table 4. Participants' understanding of individual NOS aspects and connections between them.

\begin{tabular}{|c|c|c|c|c|c|c|c|}
\hline \multirow[b]{2}{*}{ No. } & \multicolumn{6}{|c|}{ NOS aspect } & \multirow[b]{2}{*}{ Connection } \\
\hline & Empirical & Inferential & Subjective & $\begin{array}{l}\text { Imaginative } \\
\text { /Creative }\end{array}$ & Tentative & Sum & \\
\hline 1 & 2 & 0 & 1 & 1 & 1 & 5 & 1 \\
\hline 2 & 5 & 1 & 1 & 1 & 1 & 9 & 4 \\
\hline 3 & 3 & 0 & 0 & 1 & 1 & 5 & 0 \\
\hline 4 & 5 & 0 & 1 & 1 & 0 & 7 & 1 \\
\hline 5 & 4 & 3 & 1 & 1 & 1 & 10 & 3 \\
\hline 6 & 7 & 2 & 1 & 1 & 1 & 12 & 5 \\
\hline 7 & 3 & 0 & 1 & 2 & 1 & 7 & 2 \\
\hline 8 & 2 & 1 & 1 & 1 & 1 & 6 & 1 \\
\hline 9 & 2 & 1 & 3 & 0 & 1 & 7 & 2 \\
\hline 10 & 3 & 0 & 1 & 0 & 2 & 6 & 2 \\
\hline 11 & 4 & 1 & 1 & 1 & 1 & 8 & 2 \\
\hline 12 & 6 & 4 & 4 & 3 & 1 & 18 & 10 \\
\hline 13 & 3 & 1 & 1 & 1 & 1 & 7 & 3 \\
\hline 14 & 4 & 0 & 1 & 1 & 1 & 7 & 0 \\
\hline 15 & 2 & 0 & 1 & 1 & 1 & 5 & 0 \\
\hline 16 & 2 & 0 & 0 & 1 & 1 & 4 & 0 \\
\hline 17 & 4 & 0 & 2 & 1 & 1 & 8 & 3 \\
\hline 18 & 3 & 2 & 0 & 1 & 1 & 7 & 2 \\
\hline 19 & 5 & 1 & 0 & 1 & 1 & 8 & 1 \\
\hline Sum & 69 & 17 & 21 & 20 & 19 & 146 & 42 \\
\hline $\mathrm{M}$ & 3.63 & 0.89 & 1.11 & 1.05 & 1.00 & 7.68 & 2.21 \\
\hline SD & 1.46 & 1.15 & 0.99 & 0.62 & 0.33 & 3.13 & 2.35 \\
\hline
\end{tabular}

\section{Results and Discussion}

This study aimed to explore 19 first-year preservice biology teachers' initial OTSs and to examine whether those OTSs correlated with their understanding of the NOS. Analysis of the data collected using the modified POSTT for measuring their OTSs revealed that, by average, the participants tended to have OTSs between 'active direct' and 'guided inquiry'. This result supported what Dahsah \& Faikhamta (2008) reported that science education reform in Thailand is in the process of transition from direct instruction towards an inquirybased one. Since these first-year preservice biology teachers had just completed basic education and were studying only one educational course in the university, it is highly likely that the expressed OTSs resulted from their prior experiences as students in schools (Lortie, 1975) where science is taught mainly through hands-on activities and/or guided inquiry, especially in the format of the 5Es inquiry cycle which is an instructional approach long supported in Thailand (Faikhamta \& Ladachart, 2016).

Analysis of the data gathered using the translated VNOS for eliciting their understanding of the NOS showed that while the empirical NOS was well realized by most of the participants, the other four aspects of the NOS were largely ignored by many participants, especially the inferential NOS, which was mostly referred to in connection with the empirical NOS (see Figure 3). It has been found in a case study by the researchers that Thai students may perceive evidence as self-evident without making inferences and reasoning (Ladachart \& Suttakun, 2012). Perhaps, this is because many Thai science teachers do not devote their time to scientific inferences based on empirical evidence (Suttakun \& Ladachart, 2013) because of them being in too much of a hurry to bring that evidence to a scientific conclusion. As a consequence, many Thai students may have less opportunities to practice making inferences based on empirical evidence (e.g., experimental results), assuming that such evidence is sufficient and self-evident, which results in understanding empirical NOS well but a lacking in the understanding of inferential NOS as appeared in this study with first-year preservice biology teachers who had just completed basic education. 


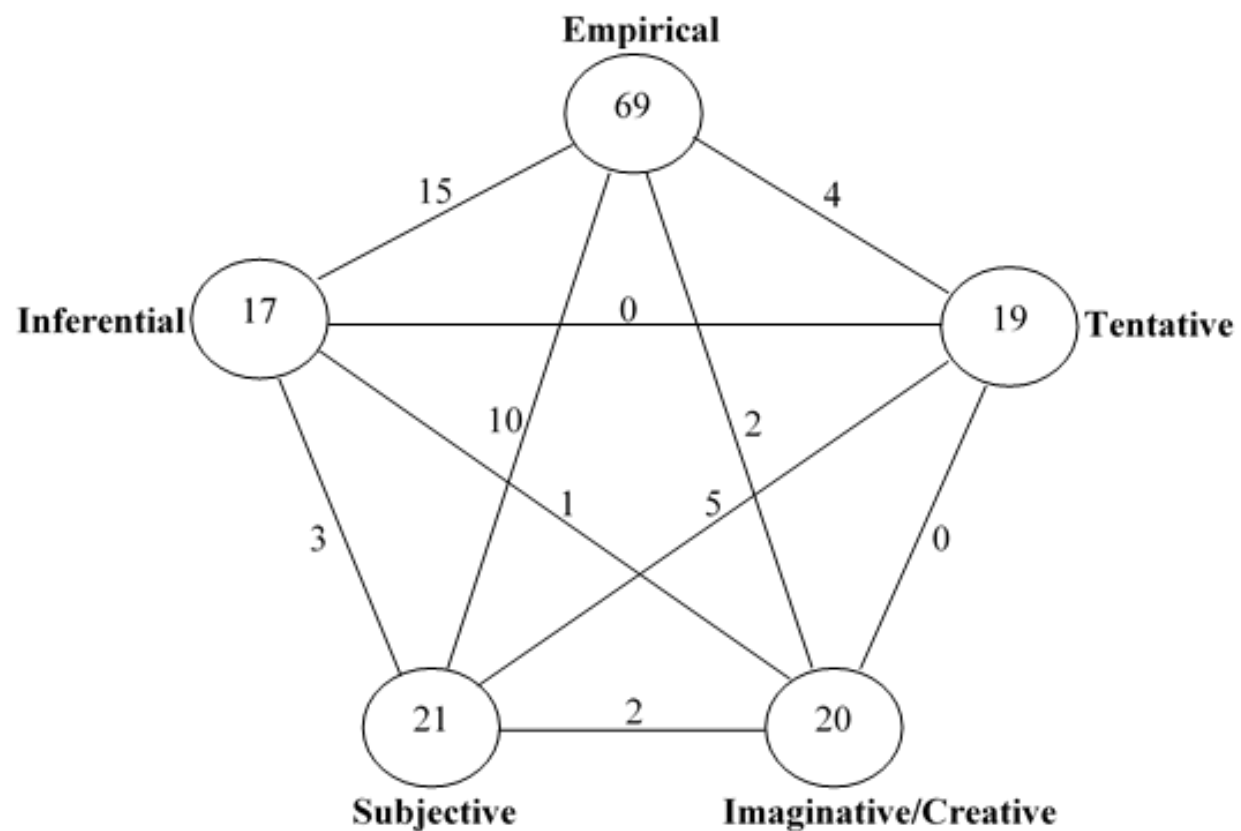

Figure 3. Participants' understanding of the NOS, as represented by a pentagon

Regarding the relationship between their understanding of the NOS and OTSs, Figure 4 visualizes a scatter plot between these two variables whose Pearson's correlation (Morgan et al. 2013) is slightly negative but not statistically significant $(\mathrm{r}=-.227, \mathrm{p}=.351)$. This result suggests that understanding of the NOS may not be a dimension of OTSs as proposed by Friedrichsen et al. (2011). Moreover, this result is not consistent with that of Tsai (2002) which showed interrelations between science teachers' beliefs of teaching, learning and science. Perhaps, what made the difference between the result of this study and that of Tsai (2002) is the nature of the participants. While the participants in Tsai's (2002) were experienced science teachers, those in this study were first-year preservice science teachers. The authors have learned from their previous study that experienced science teachers tend to have a strongly held conception regarding teaching, the dimension of OTS according to Friedrichsen et al. (2011), while novice science teachers tend to possess a looser conception of teaching (Ladachart, 2011). Perhaps, this may be the reason why the freshmen preservice biology teachers in the present study did not show a positive tendency as regards their initial OTSs and understanding of the NOS as it appeared in Tsai's (2002) study.

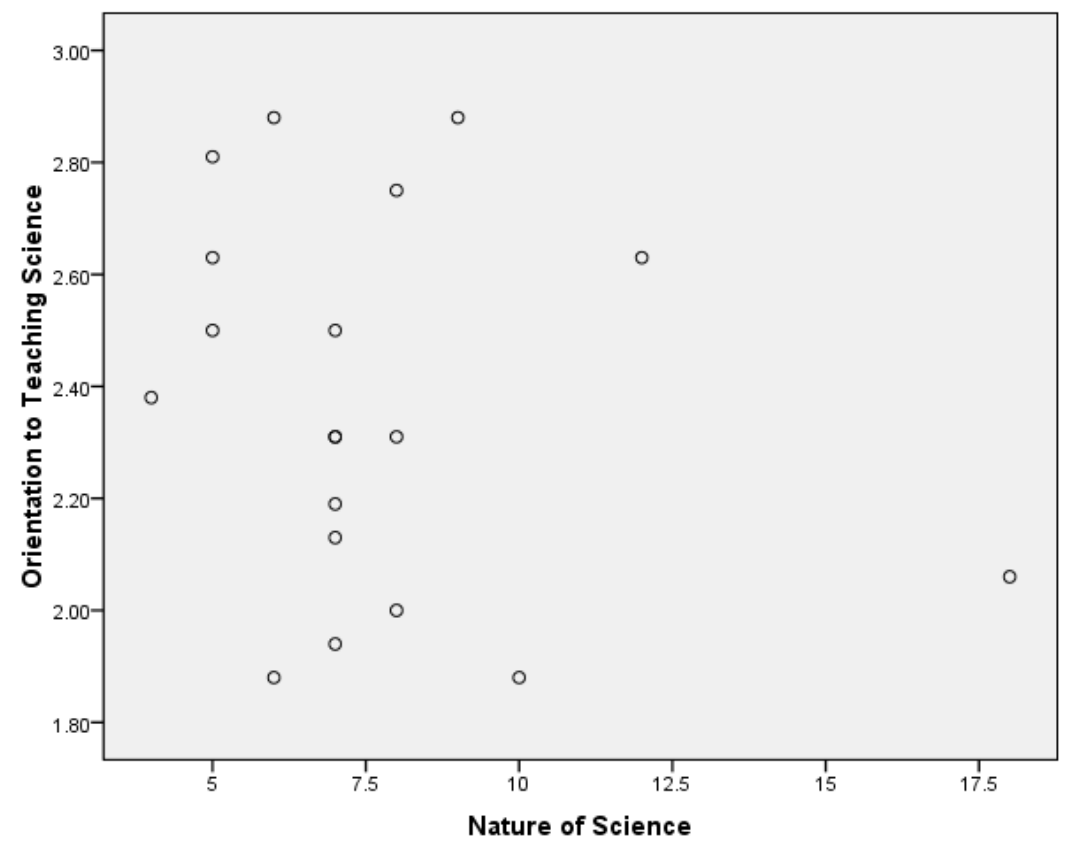

Figure 4. Participants' OTSs and understanding of NOS 
On the other hand, the result of this study supported that of Demirdogen (2016) in that preservice science teachers' understanding of the NOS has no direct interaction with their PCK. In other words, possessing an informed understanding of the NOS (e.g., an understanding of how scientific knowledge is constructed) does not guarantee that science teachers will teach science in manners that allow their students to construct scientific knowledge (Lederman, 1999; Mellado, 1997). It is more likely that the NOS is viewed as a subject-specific content like combustion, electricity and plant growth (Faikhamta, 2013), and not as a component or dimension of OTSs (Kind, 2016). As in the case of teachers teaching other subjects in science, science teachers should be facilitated to develop PCK for teaching the NOS (Hanuscin, Lee, \& Akerson, 2011) since learning about the NOS tends to be like learning a cognitive domain (Abd-El-Khalick \& Lederman, 2000). Developing the understanding of the NOS alone does not necessarily lead to inquiry-based OTSs unless other supporting experiences (see Avraamidou, 2013) are provided.

\section{Implications}

This study has both theoretical and practical contributions. As for the theoretical one, it makes an issue of the nature of OTSs clearer in that OTSs, at least those held by first-year preservice biology teachers in the study, tend not to be associated with their understanding of the NOS. This theoretical contribution leads to a practical one, suggesting that science teacher educators cannot assume that developing informed understanding of the NOS among preservice science teachers will lead to inquiry-based OTSs. However, this does not devalue the efforts made in developing preservice science teachers' understanding of the NOS, which is a component of scientific literacy as a key goal of science education (Lederman, Lederman, \& Antink, 2006). In other words, developing inquiry-based OTSs may need a different pathway. Based on Schneider \& Plasman's (2011) review on learning progression for PCK, which suggests that "teacher thinking appears to progress first to thinking about learners, then to thinking about teaching, and finally to building a repertoire" (pp. 555), focusing on students' nature and characteristics (e.g., their preconceptions about scientific phenomena) may serve as a starting point in the preparation of preservice science teachers to develop inquiry-based OTSs and PCK. Recently, research has found strong connections among science teachers' orientations to science teaching, knowledge of student understanding, and knowledge of instructional strategies (Suh \& Park, 2017).

\section{References}

Abd-El-Khalick, F. \& Lederman, N. G. (2000). Improving science teachers' conceptions of nature of science: A critical review of the literature. International Journal of Science Education, 22(7), 665-701.

Abell, S. K. (2008). Twenty years later: Does pedagogical content knowledge remain a useful idea? International Journal of Science Education, 30(10), 1405-1416.

Avraamidou, L. (2013). Prospective elementary teachers' science teaching orientations and experiences that impacted their development. International Journal of Science Education, 35(10), 1698-1724.

Boesdorfer, S. \& Lorsbach, A. (2014). PCK in action: Examining one chemistry teachers' practices through the lens of her orientation toward science teaching. International Journal of Science Education, 36(13), 2111-2132.

Britner, S. L. \& Finson, K. D. (2005). Preservice teachers' reflections on their growth in an inquiry-oriented science pedagogy course. Journal of Elementary Science Education, 17(1), 39-54.

Brown, P., Friedrichsen, P., \& Abell, S. (2013). The development of prospective secondary biology teachers PCK. Journal of Science Teacher Education, 24(1), 133-155.

Bureau of Academic Affairs and Educational Standards. (2010). Indicators and Core Learning Content in Science According to the Basic Education Core Curriculum B.E. 2551. Bangkok: Agricultural Cooperative Federation of Thailand.

Cobern, W. W., Schuster, D., Adams, B., Skjold, B. A., Mugaloglu, E. Z., Bentz, A., \& Sparks, K. (2014). Pedagogy of science teaching tests: Formative assessments of science teaching orientations. International Journal of Science Education, 36(13), 2265-2288.

Dahsah, C. \& Faikhamta, C. (2008). Science education in Thailand: Science curriculum reform in transition. In R. K. Coll \& N. Taylor (Eds.). Science education in context: An international examination of the influence of context on science curricula development and implementation (pp. 291-300). Rotterdam: Sense Publishers.

Demirdogen, B. (2016). Interaction between science teaching orientation and pedagogical content knowledge components. Journal of Science Teacher Education, 27(5), 495-532.

Eick, C. J. \& Reed, C. J. (2002). What makes an inquiry-oriented science teacher? The influence of learning histories on student teacher role identity and practice. Science Education, 86(3), 401-416. 
Faikhamta, C. (2013). The development of in-service science teachers' understandings of and orientations to teaching the nature of science within a PCK-based NOS course. Research in Science Education, 43(2), 847-869.

Faikhamta, C. \& Ladachart, L. (2016). Science education in Thailand: Moving through crisis to opportunity. In M, Chiu (Ed.). Science education research and practice in Asia (pp. 197-214). Springer: Singapore.

Friedrichsen, P. M. \& Dana, T. M. (2003). Using a card-sorting task to elicit and clarify science teaching orientations. Journal of Science Teacher Education, 14(4), 291-309.

Friedrichsen, P. M. \& Dana, T. M. (2005). Substantive-level theory of highly regarded secondary biology teachers' science teaching orientations. Journal of Research in Science Teaching, 42(2), 218-244.

Friedrichsen, P., van Driel, J. H., \& Abell, S. K. (2011). Taking a closer look at science teaching orientations. Science Education, 95(2), 358-376.

Hanuscin, D. L., Lee, M. H., \& Akerson, V. L. (2011). Elementary teachers' pedagogical content knowledge for teaching the nature of science. Science Education, 95(1), 145-167.

Kind, V. (2016). Preservice science teachers' science teaching orientations and beliefs about science. Science Education, 100(1), 122-152.

Ladachart, L. (2011). Thai physics teachers' conceptions about teaching. Journal of Science and Mathematics Education in Southeast Asia, 34(2), 174-202.

Ladachart, L. \& Suttakun, L. (2012). Exploring and developing tenth-grade students' understandings of nature of science. Princess of Naradhivas University Journal, 4(2), 73-90.

Lederman, N. G. (1992). Students' and teachers' conceptions of the nature of science: A review of the research. Journal of Research in Science Teaching, 29(4), 331-359.

Lederman, N. G. (1999). Teachers' understanding of the nature of science and classroom practice: Factors that facilitate or impede the relationship. Journal of Research in Science Teaching, 36(8), 916-929.

Lederman, N. G., Abd-El-Khalick, F., Bell, R. L., \& Schwartz, R. S. (2002). Views of nature of science questionnaire: Toward valid and meaningful assessment of learners' conceptions of nature of science. Journal of Research in Science Teaching, 39(6), 497-521.

Lederman, N. G., Lederman, J. S., \& Antink, A. (2006). Nature of science and scientific inquiry as contexts for the learning of science and achievement of scientific literacy. International Journal of Education in Mathematics, Science and Technology, 1(3), 138-147.

Lortie, D. C. (1975). Schoolteacher: A Sociological Study. Chicago: The University of Chicago Press.

Magnusson, S., Krajcik, J., \& Borko, H. (1999). Nature, sources, and development of pedagogical content knowledge for science teaching. In J. Gess-Newsome \& N. G. Lederman (Eds.), Examining pedagogical content knowledge: The construct and its implications for science education (pp. 95-132). Dordrecht: Kluwer Academic Publishers.

Mellado, V. (1997). Preservice teachers' classroom practice and their conceptions of the nature of science. Science \& Education, 6(4), 331-354.

Morgan, G. A., Leech, N. L., Gloeckner, G. W., \& Barrett, K. C. (2013). IBM SPSS for Introductory Statistics: Use and Interpretation. (5th Edition). New York: Routledge.

Nargund-Joshi, V., Park Rogers, M. A., \& Akerson, V. L. (2011). Exploring Indian secondary teachers' orientations and practice for teaching science in an era of reform. Journal of Research in Science Teaching, 48(6), 624-647.

Park, S. \& Chen, Y. (2012). Mapping out the integration of the components of pedagogical content knowledge (PCK): Examples from high school biology classrooms. Journal of Research in Science Teaching, 49(7), 922-941.

Ramnarain, U., Nampota, D., \& Schuster, D. (2016). The spectrum of pedagogical orientation of Malawian and South African physical science teachers towards inquiry. African Journal of Research in Mathematics, Science, and Technology Education, 20(2), 119-130.

Ramnarain, U. \& Schuster, D. (2014). The pedagogical orientations of South African physical sciences teachers towards inquiry or direct instructional approaches. Research in Science Education, 44(4), 627-650.

Richardson, V. 1991. Significant and worthwhile change in teaching practice. Educational Researcher, 19(7), 10-18.

Schneider, R. M. \& Plasman, K. (2011). Science teacher learning progressions: A review of science teachers' pedagogical content knowledge development. Review on Educational Research, 81(4), 530-565.

Shulman, L. S. (1986). Those who understand: Knowledge growth in teaching. Educational Researcher, 15(2), 4-14.

Shulman, L. S. (1987). Knowledge and teaching: Foundations of the new reform. Harvard Educational Review, 57(1), 1-22.

Suh, J. K. \& Park, S. (2017). Exploring the relationship between pedagogical content knowledge (PCK) and sustainability of an innovative science teaching approach. Teaching and Teacher Education, 64, 246-259. 
Suttakun, L \& Ladachart, L. (2013). Fourth grade students' scientific reasoning. Naresuan University Journal: Science and Technology, 21(3), 107-123.

Tsai, C. -C. (2002). Nested epistemologies: Science teachers' beliefs of teaching, learning and science. International Journal of Science Education, 24(8), 771-783.

van Driel, J. H., Verloop, N., \& de Vos, W. (1998). Developing science teachers' pedagogical content knowledge. Journal of Research in Science Teaching, 35(6), 673-695.

Veal, W. R. \& Makinster, J. G. (1999). Pedagogical content knowledge taxonomies. Electronic Journal of Science Education, 3(4). Retrieved from http://ejse.southwestern.edu/article/view/7615.

\section{Author Information}

\section{Luecha Ladachart}

School of Education, University of Phayao

19, Village No. 2, Mae Ka, Mueang, Phayao, 56000,

Thailand

Contact e-mail: ladachart@gmail.com 